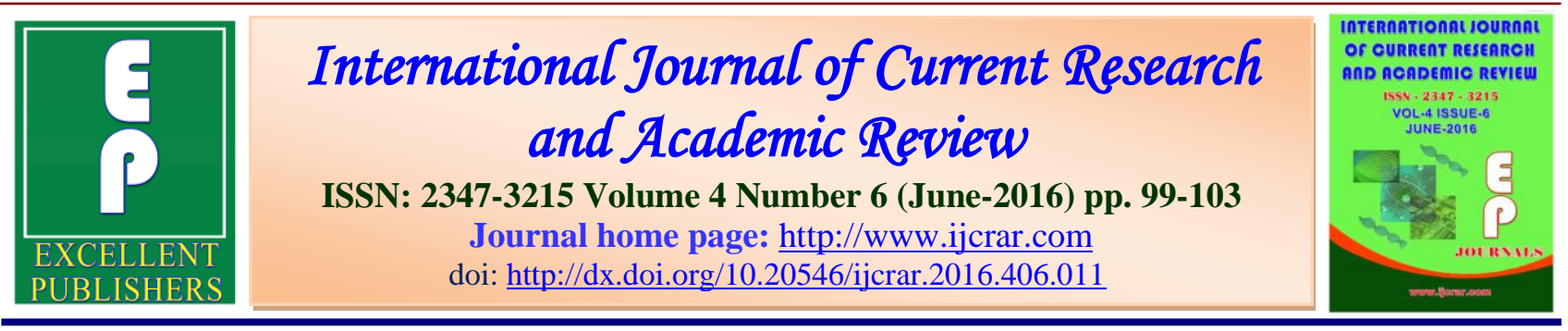

\title{
Life Satisfaction of Elderly Living in Varying Familial Patterns in Relation to Available Familial Support Systems
}

\author{
Deepti Salotra $^{1}$ * and Neeru Sharma ${ }^{2}$ \\ ${ }^{1}$ Trikuta Nagar Jammu, University of Jammu, India \\ ${ }^{2}$ Professor and Head Department of Home Science, University of Jammu, India \\ *Corresponding author
}

\begin{tabular}{l|l} 
KEYWORDS & A B S T R A C T \\
\cline { 2 - 2 } $\begin{array}{l}\text { Elderly, } \\
\text { Modernization, } \\
\text { Urbanization, }\end{array}$ & $\begin{array}{l}\text { Changing value system on account of urbanization and modernization is } \\
\text { disturbing the traditional harmonious relationship between family and } \\
\text { elderly parents. The present research is an exploratory attempt to study the } \\
\text { "Latterns. }\end{array}$ \\
$\begin{array}{l}\text { "Life satisfaction of elderly living in varying familial patterns in relation to } \\
\text { available familial support systems". The sample comprised of 150 elderly } \\
\text { (males and females) in the age range of } 60 \text { years and above who are living } \\
\text { in varying familial patterns, selected through multistage sampling technique } \\
\text { from urban areas of Jammu city. The tools used for data collection were - } \\
\text { Observation, Interview schedule and Life satisfaction Scale which was } \\
\text { subjected to both content and statistical analysis. The results reveal that } \\
\text { majority of the elderly were partially satisfied with their lives. Most of the } \\
\text { elderly show satisfaction with the available familial support while many of } \\
\text { them are dissatisfied with it, especially the lack of concern' shown by the } \\
\text { married sons who, they believe, perceive them as burden whereas the } \\
\text { younger generation feel that they often have lack time and patience to care } \\
\text { for their elderly grandparents. Significant gender differences are observed in } \\
\text { all dimensions of Life Satisfaction Scale. }\end{array}$ \\
\hline
\end{tabular}

\section{Introduction}

In the developed world, chronological time plays a paramount role. The age of 60 or 65 , roughly equivalent to retirement ages in most developed countries is said to be the beginning of old age. Other socially constructed meanings of age are more significant such as the roles assigned to older people; in some cases it is the loss of roles accompanying physical decline which is significant in defining "old age" (Gorman, 2000). The UN has not adopted a standard criterion, but generally use 60+ years to refer to the older population United Nations, 2001).

Today's global economy and the simultaneous fast pace changes in the living arrangements of the Indian family have affected the family's solidarity and 
competence in providing care to all its members. The term 'living arrangement' is used to refer to one's house hold structure (Palloni, 2001). Living arrangement is an important component in dealing the welfare of any specific group. At the macro level numerous changes have taken place in the Indian society as a whole.

Colonization of the Indian society had exposed it to new cultural values and belief systems with subsequent erosion of the economic roots. It has also been reiterated by Gangrade (1999) that Indian society however, had been undergoing rapid transformation under the impact of industrialization, urbanization, comercialization, individualism etc. The change in the pattern of production and consumption ultimately has an effect on the micro unit of the society i.e. the family, and home in the roles and relationship of its members. The elderly regards family residence as the most secure place, as observed by Biswas (1994).

Care of the elderly, in Indian society, has been one of the primary functions of the family system since time immemorial. Living with male children is the most preferred living arrangement for the elderly in India. An opinion survey of the elderly in India reveal that an overwhelming proportion desire family residential arrangements during their old age. (Kumar, 1997). But it is widely known that the erosion of the traditional norm whereby the elderly generally live with children or relatives reduces the well being of the older population (Palloni, 2001). The changing values and life styles due to urbanization is resulting in increasing intergenerational distance and decreasing family cohesiveness. The present research makes an attempt to document the variations in the existing familial living patterns and to explore the satisfaction level in context to their available familial support systems.

\section{Research Methodology}

Sample: The sample for the present study comprised of 150 elderly people (70 men and 80 women) in the age group of 60 years and above.

\section{Criteria for Sample Selection}

Age: Elderly in the age group of 60 years and above were selected.

Sex: Both males and females were included as the sample.

Duration of stay and Residence: Only those aged and their families were included who have been living in Jammu for the last 30 years.

\section{Sampling Technique}

The sample for the study was selected through multistage sampling procedure, from urban areas of Jammu City and its urban outgrowth as notified in advertisement (No. DIP/J-1382 dated 19.08.2004, Government. of Jammu and Kashmir, civil Secretariat: Housing and Urban Development Department). From the list of 113 urban areas, 23 areas were selected through systematic random sampling i.e. every $5^{\text {th }}$ area was selected. From this area the sample was systematically selected after the presurvey through which the different family patterns, in which the aged are living with support systems were identified.

\section{Tools Used:}

\section{Observation}

Observation of living conditions and familial interactions of the elderly and their families 


\section{Interview Schedule}

Interview schedule for aged was used to derive the detailed information regarding familial interaction of elderly parents, attitude towards life, familial support during illness and satisfaction regarding care provided by children.

\section{Rating Scale for elderly}

\section{Life Satisfaction Scale}

All the tools were pre tested on $10 \%$ of the sample other than that used for present study. Data gathered through the administration of tools were subjected to both quantitative and qualitative analysis.

\section{Results and Discussion}

The results of the study reveal the various family patterns, in which elderly are living, after conducting survey in Jammu City and its urban outgrowths. The varying familial patterns have emerged due to modernization and migration of the elderly or their families from their native places, which has eroded the traditional joint family system into nuclear families taking various forms. The survey reveals that there are 5 varying familial patterns in which elderly are living in Jammu. Out of the total sub- sample ( $\mathrm{n}=70$ males and 80 females) 'two' of the patterns are based on couples i.e. $43 \%$ are Couples living with children; 'four' patterns are based on the surviving spouse in different setting i.e. $50 \%$ widowers and $27 \%$ widows living with married sons, $35 \%$ widows and $7 \%$ widowers are living with married daughters.

The above table reveals that most of the elderly respondents i.e. couples (CLWC; $12 \%$ females and $9 \%$ males) show "average" level of satisfaction on life satisfaction scale. On the basis of observation, it is concluded that elderly couples who are living with children (CLWC) are dissatisfied with their lives. The results reveal that elderly parents are not satisfied by the support provided by their married sons and daughter-in-laws as intergenerational relationship and role of women in the family are changing which has an affect on the care of elderly in the family.

Table.1 Family patterns of the Elderly living in Jammu city $(\mathrm{N}=150)$

\begin{tabular}{|l|cc|rr|}
\hline \multicolumn{1}{|c|}{ Settings } & f & \multicolumn{2}{c|}{ Females (n=70) } \\
& f & f & $\%$ \\
\hline Couples living with children (CLWC) & 30 & 43 & 30 & 43 \\
\hline Widows living with married children (WLMC) & -- & -- & 22 & 27.50 \\
\hline Widowers living with married children (WDLMC) & 35 & 50 & -- & 35 \\
\hline Widows living with married daughters (WLMD) & -- & -- & 28 & -- \\
\hline $\begin{array}{l}\text { Widowers living with married daughters } \\
\text { (WDLMD) }\end{array}$ & 5 & & -- & -14 \\
\hline
\end{tabular}

$\%$ ages in parentheses 
Int.J.Curr.Res.Aca.Rev.2016; 4(6): 99-103

Table.2 Level of Life Satisfaction of Elderly.(N=150)

\begin{tabular}{|c|c|c|c|c|c|c|}
\hline Levels of Life & \multicolumn{2}{|c|}{ CLWC } & \multirow{2}{*}{$\begin{array}{l}\text { WLMC } \\
(\mathrm{n}=22)\end{array}$} & \multirow{2}{*}{$\begin{array}{l}\text { WDLMC } \\
(\mathrm{n}=35)\end{array}$} & \multirow{2}{*}{$\begin{array}{l}\text { WLMD } \\
(\mathrm{n}=28)\end{array}$} & \multirow{2}{*}{$\begin{array}{c}\text { WDLMD } \\
(\mathrm{n}=5)\end{array}$} \\
\hline $\begin{array}{l}\text { Satisfaction } \\
\text { Scale }\end{array}$ & $\begin{array}{l}\text { Males } \\
(\mathrm{n}=30)\end{array}$ & $\begin{array}{l}\text { Females } \\
(\mathrm{n}=30)\end{array}$ & & & & \\
\hline High & $8(15.09 \%)$ & $1(2 \%)$ & $4(7.54 \%)$ & $7(13.20 \%)$ & $4(7.54 \%)$ & \\
\hline Average & $21(9.09 \%)$ & $28(12.12 \%)$ & $16(7 \%)$ & $26(11.25 \%)$ & $20(9 \%)$ & $5(2.16 \%)$ \\
\hline Low & $1(6.25 \%)$ & $1(6.25 \%)$ & $2(12.5 \%)$ & $2(12.5 \%)$ & $4(25 \%)$ & ------------ \\
\hline
\end{tabular}

\%ages in parentheses

CLWC: Couples living with children

WLMC: Widows living with married children

WDLMC: Widowers living with married children

WLMD: Widows living with married daughters

WDLMD: Widowers living with married daughters

Table.3 Gender differences in Life Satisfaction of Elderly living with Support system

\begin{tabular}{|c|c|c|c|c|c|}
\hline \multirow{2}{*}{ Gender Differences } & \multicolumn{2}{|c|}{ ELWS (Males) } & \multicolumn{2}{|c|}{ ELWS(Females) } & \multirow{2}{*}{$\mathrm{t}$-Value } \\
\hline & Mean & S.D. & Mean & S.D. & \\
\hline Life Satisfaction & 123.21 & 17.645 & 112.41 & 20.021 & $3.520 * *$ \\
\hline
\end{tabular}

**Significant at 0.01 level ELWS: Elderly living with support

Significant gender differences are observed in satisfaction level of elderly. In the scores on life satisfaction, males showing higher scores $(x=123.21, \mathrm{t}=3.520, \mathrm{p}<0.01)$ than females $(x=112.41)$ among elderly living with support. It was observed that most of the elderly livings with children are looked after by their spouses when they fall ill and this is because of growing generation and communication gap. It is clear from the observations that children are not willing to take responsibility of their elderly parents due to lack of time because they are busy in their own family and work. Elderly females are dissatisfied with the behaviour of their married sons and daughter-in-laws. Even their grandchildren also do not prefer to spend time with their grandparents especially grandmothers as they get irritated by their sermons regarding "do's and don'ts". Paul's (2000) observations, from a study in Jammu District, commensurate with the findings of the present research that after attaining the age of 55 years, there is a decrease in close relationship with children, the reason for this being an authoritative attitude and the busy schedule of their children.

\section{Conclusion}

On the basis of the discussion above, it is concluded that those elderly who are living with spouses are more satisfied than those who are living with their married children because the former group has no expectations from their children whereas for the latter group, it was seen that elders usually felt disappointed with the care provided by their children. Elderly who are living with their married daughters are worst placed as they feel a strong sense of loss of status and the security of their homes. The policy implications that are derived from the 
present study are at individual, familial, societal and governmental level which are a few positive approaches meant for adding life to the "grey years".

\section{References}

Biswas, S.K. 1994. Implications of Population and Aging. In C.Ramachandra and B.Shah (Eds.) Public Health Record Implications of Aging in India. New Delhi: Indian Council of Medical Research.

Gangrade, K.D. 1999. Emerging conception of Ageing in India. A Socio-Cultural Perspective. Eastern Anthropologist, 42(2): 151-159.

Kumar, V. 1997. Aging in India: An Overview. Indian J. Med. Res., 106: 257-264.
Palloni, A. 2001. Living Arrangements of Older Persons. Population Bulletin of the United Nations, Special Issue No. 42/43: 54-110.

Paul, S. 2000. Perception of LifeSatisfaction among aged in context of the Familial Support Systems. An Unpublished M.Sc. Dissertation, PostGraduate Department of Home Science, University of Jammu, Jammu.

Patil, P.B., Gaonkar, V., Yadav, V.S. 2009. Influence of family solidarity on life satisfaction of the elderly. J. Dairying, Foods and Home Sci., 28(2): 149-151.

United Nations Population Division. 2001. Department of Economic and Social Affairs. Population ageing. United Nations Publication.

\section{How to cite this article:}

Deepti Salotra and Neeru Sharma. 2016. Life Satisfaction of Elderly Living in Varying Familial Patterns in Relation to Available Familial Support Systems. Int.J.Curr.Res.Aca.Rev.4(6): 99-103. doi: http://dx.doi.org/10.20546/ijcrar.2016.406.011 